\title{
Communal Conflict, Internal Displacement and Livelihood Security: An Analysis of the Agila Situation
}

\author{
Sunday Orinya \\ Department of Political Science \\ Federal University, Lafia, Nasarawa State
}

\begin{abstract}
The communal conflict between the people of Agila in Benue State and Ngbo of Ebonyi State of Nigeria over land has been trans-generational. Since 1925 when the first out-break of hostility between the two communities was reported, the natural resource conflict over land has defied all attempts at resolving it. In its dynamics of degeneration, the conflict has witnessed instances of killings, kidnapping and wanton destruction of property resulting in internal population displacement and livelihood crisis. This paper analyses the impact of population displacement arising from the Agila/Ngbo communal conflict on livelihood security in Agila community. Relying on qualitative descriptive analysis of empirical data and secondary sources, the paper posits that population displacement arising from this conflict has had dire impact on livelihood security on the depleted population in Agila community. The paper recommends a strategic relief and humanitarian assistance by government and donour agencies to the displaced persons and urgent pragmatic steps through a process of conflict analysis to resolve the age-long conflict.
\end{abstract}

Keywords: Communal conflict, internal displacement, livelihood security, Agila

\section{INTRODUCTION}

Agila is an Idoma-speaking community in Ado Local Government of Benue State ravaged by decades of communal conflict. Agila is both the name of a community and a town. The community is made up of two council wards out of the ten in the local government. They are Apa and Akpoge/Ogbilolo Wards. Agila town is the traditional headquarters of the old Agila District. Its location is along the Benue/Ebonyi and Benue/Enugu inter state boundary lines. Ngbo community of Ebonyi State and Nkalaha and Ehamufu communities in Enugu State bound it in the south. It has boundary to the north with Igumale community in Benue state. The inter-state boundary between Benue and Ebonyi also served as boundary between the defunct Northern and Southern Protectorates during the colonial era. It has remained a source of protracted conflict between Agila and Ngbo communities.

While dispute over land has been the factor in the almost a century old conflict between Agila and her Ngbo neighbour in Ebonyi State (Tribune, 2012), the royal versus non-royal families conflict which broke out in the $90 \mathrm{~s}$ in the community has proved to be the greatest undoing of unity in the community (WEP, 2009; Otokpa, 2014).

The intra-communal conflict between the two families generated hatred never witnessed in the history of the Agila people (Otokpa, 2014). The resort to the use of lethal weapons forced some people to migrate from the community for safety resulting in population displacement. The increasing frequency of violent conflicts between Agila and Ngbo has depleted the thickly populated rural settlement. Residents of many farm settlements have been forced to migrate. Since the advent of democratic rule in 1999, the natural resource conflict has been framed in terms of ethnic conflict giving rise to the emergence of ethnic militia and use of sophisticated weapons.

In the dynamics of its degeneration, Agila has witnessed loss of lives, population displacement, destruction of farms, disruption of economic and social activities. Many of the residents have been forced to leave their ancestral homes while local and state government officials working in schools, health clinics in the community have been forced to flee for safety. Churches, schools, health facilities have been relocated from their original locations. 


\section{Sunday Orinya}

The resultant internal displacement occasioned by this communal conflicts has not only made life miserable for those running for safety but has also generated livelihood crisis for the few left behind to defend their ancestral home. The persistence of the conflict means that the population of the community is continuously being depleted and those who resist the attempt to be uprooted from their ancestral home do that at great physical, social and economic costs.

Most works relating to population displacement, (Ibeanu 2003; Egwu, Kure \& Salihu, 2003); Best \& Idyorough, 2003), tend to focus on the challenges faced by internally displaced persons from sociopolitical conflicts. According to Blench (2004), natural resource conflict is more dispersed and usually occurs in inaccessible places and often goes unreported. Consequently, some salient dimensions of its impact are usually ignored especially when the entire community is not displaced. This study therefore, explores the livelihood security situation in Agila community in the context of its communal disturbances with the Ngbo people with a view to suggesting how to remedy it.

The paper is divided into seven sections. Section one is the introduction, while section two deals with methodology/theoretical framework. Section three deals with the conceptual explication while four is an overview of communal conflicts in Agila. Section five deals with population displacement while section six examines the implication on livelihood. Conclusion and recommendations are contained in section seven.

\section{Methodology AND TheORETiCAL FrameWORK}

This paper is a qualitative study relying on data from primary and secondary sources for descriptive analysis. For primary sources, the paper relied on face-to-face and telephone interviews with key informants resident in Agila and those displaced as a result of communal conflicts. They were properly selected based on their knowledge of the socio-economic history of the community as well as the conflict situation. The paper relied on the use of library and government documents as secondary sources. These include academic literature, communiqués, media reports, archival materials, position papers as well as official reports.

For purpose of analysis, the paper adopts the Sustainable Livelihood Approach (SLA) as a framework of analysis. According to Sakdaolrak (2014) the approach was theoretically given birth to in the works of Polanyi (1977) but was popularized by the Department for International Development (DFID) of the British government in the 90s as a development strategy. DFID sees SLA as framework for analysis to understand what 'is' and what can be done (Farrington 2001).

The approach identifies physical, social, natural, economic or financial and human capitals as critical factors in explaining sustenance of livelihood. As an analytical framework it focuses on the assessment of the individual, household, village or group using the five livelihood capitals namely human, physical, economic, social and natural as units of analysis (Springer, 2014).

SLA demonstrates sufficient analytical capacity in explaining the current livelihood situation in Agila community. According to Springer (2014, p. 18), SLA is an analysis of peoples' current livelihood and what is needed for an 'enhancement', and useful in avoiding inappropriate interventions. It focuses on people-centeredness and examines the coping and survival strategies of people at risk (Sakdapolrak, 2014).

A major strength of SLA is that it is integrative, locally embedded, cross-sectoral and informed by deep field engagement and commitment to action (Scoones, 2009, p. 173). As observed by Morse \& McNamara (2014), SLA could result in recommendations that people themselves may be able to put into practice rather than depend upon the actions of outsiders.

\section{Conceptual Explication}

For the purpose of clarification, three key concepts used in this paper need explication to bring out the context in which they were used. They are Communal conflict, internal displacement and livelihood crisis. 


\subsection{Communal Conflict}

Communal conflict is seen as conflict in which the participants or parties to the conflict are communitybased identity groups. It is usually a function of communal identity. Communal identity is defined as subjective group identification based on common history, a common culture or common core values (Brosche and Elfversson, 2012:35). Communal violence is thus a deeply emotional basis of mobilization that is not merely distinguishing groups from one another but can dehumanize and demonize the other groups, as it is characterized by violence, emotion and difficult to solve (Nnoli, 2003)

A distinctive character of communal conflict is that parties to the conflict are usually subjects of the same state (Elfversson, 2013). They are non-state groups, but unlike other conflicts, disputes are not always on material resources but also involve status, culture, identity and value. The membership of a communal group is not attained but ascribed and as such communal identity has the symbolic capability to define for the individual the totality of his/her hopes, fears and sense of the future (Nnoli, 2003, p. 1).

Communal conflict is an expression of disagreement over the control of resources. Communal violence can then be seen as a resort to the use of lethal weapons as a means of resolving conflict between nonstate identity groups (communities). It is expressed in violent confrontations such as between villages, among ethnic groups in a town or the nation at large, between a village or ethnic group and the state, violence between a religious group and the state, or violence between different ethnic or religious groups within the ruling circle (Nnoli 2003:v). As an identity conflict, communal violence is "defined in ethnic, communal, regional and religious terms, either pitched against themselves in deadly confrontation, or against the central government" (Egwu, 2006:408).

\subsection{Internal Population Displacement}

A situation of population displacement occurs when people are forced to leave their places of residence owing to a life-threatening condition. It could be created by man, as in the case of violent conflict such as war or natural disaster like earthquake. A distinctive character of displacement is the element of force. Internal population displacement is thus a situation when group or groups are forced to migrate within national border owing to hostile situation in their ancestral home or place of residence emanating from conflict or natural disaster.

According to Ibeanu (2003), displacement-generating conflicts in Nigeria are of three types. These are resource-based, identity-based and participation-based conflicts. In any of these cases those affected have little or no chances to stay behind owing to the livelihood crisis that usually follow such conditions. According to the United Nations (1998) Guiding Principles on internally displace persons:

...internally displaced persons are persons or groups of persons who have been forced or obliged to flee or to leave their homes or places of habitual residence, in particular as a result of or in order to avoid the effects of armed conflict, situations of generalized violence, violations of human rights or natural or human-made disasters, and who have not crossed an internationally recognized state border.

By this definition, an internally displaced person (IDP) becomes a refugee when he or she crosses an internationally recognized border.

\subsection{Livelihood Security}

According to White Paper Carney (1998) cited in Morse, McNamara \& Acholo (2009, p. 4) “A livelihood comprises the capabilities, assets (including both material and social resources) and activities required for a means of living". Livelihood crisis arises when a population is faced with dire multi-faceted challenges that make sustenance of human survival difficult. The definition of livelihood by Chambers and Conway (1992) provides analytical basis in which livelihood is used in this discourse. According to them:

Livelihood comprises the capabilities, assets (stores, resources, claims and access) and activities required for a means of living; a livelihood is sustainable which can cope with and recover from stress and shocks, maintain or enhance its capabilities and assets, and provide sustainable livelihood opportunities for the next generation; and which contributes net benefits to other livelihood at the local and global levels and in the short and long term (Chambers \& Conway, 1992, p. 6). 


\section{Sunday Orinya}

There is Livelihood security in a situation when there is the presence of natural, material and social resources in good measure. Livelihood crisis or insecurity ensues in a system when chances of recovery from stress and shocks as well as ability to maintain or enhance capabilities for sustainable livelihood are lacking. This is due to lack of natural, material and social resources. As observed by Gaillard, Maced, Stasiak, Berre \& Epsaldon (2009, p. 121) livelihood includes complex, contextual, diverse and dynamic strategies developed by households to meet their needs. The Department for International Development of the British government DFID following Scoones (1998) identifies five diverse capitals for sustaining livelihood. These are physical, social, natural, economic or financial and human capitals. When these capitals are unavailable or cannot be accessed livelihood crisis is imminent.

\section{Overview of Communal Conflicts and Population Displacement in Agila COMMUNITY}

Displacement-generating communal conflicts in Nigeria are categorized into resource-based, identitybased and participation based conflicts (Ibeanu, 2003). Conflicts in Agila community, by their nature, exhibit the character of both resource and identity-based conflicts. The inter-communal conflict with Ngbo is a struggle for control of land, which is a natural resource.

\subsection{Communal Conflicts in Agila: Historical-cum-Contextual Overview}

While the land dispute between Agila and Ngbo is inter-communal and resource-based, the royal and nonroyal families feud, which engulfed the community in the 90 s is intra-communal and identity-based. Conflicts of this nature are usually protracted and difficult to resolve (Nnoli, 2003). Agila is an Idomaspeaking community in Benue State while Ngbo belongs to the Igbo ethnic group in Ebonyi State. The conflict takes place along the Akpoge/Ogbilolo Ward of Ado local government boundary with Ngbo of Ohaukwu local government of Ebonyi State. The formal report of inter-communal conflict between the two communities was reported first during the period of colonial rule. Since then, Agila community has witnessed both intra and inter-communal conflicts resulting in loss of lives, destruction of properties and population displacement (WEP, 2009). The major one has been the one between her and Ngbo community. In its study WEP (2009, p. 18) reported also that there is "a protracted inter-ethnic conflict between the Agila people in Benue State (of the Idoma ethnic stock) with Ngbo people (of Igbo extraction).

The inter-communal conflict with the Ngbos of Ebonyi State has its root in the struggle for control of land resource arising from colonial government policy on boundary demarcation (WEP, 2009; Otokpa, 2014). The intra-communal feud between the royal and non-royal families was triggered by dispute over the use of royal drum at a wedding reception could fit into identity-based conflict (Otokpa, 2014). Both have led to devastating effects on the community (WEP, 2009).

The two categories of conflict have had serious impact on population displacement in the community. This is due to the resort to violence and its consequence on human safety. As pointed out by Nnoli (2003, p. 3) "communal identity is a deeply emotional basis of mobilization that merely distinguishes one group from the other but can also dehumanize and demonize the other group". Agila and Ngbo communities have different identities. They belong to different ethnic group, different local governments, different states, and different geo-political zones. This accounts partly for the protracted and violent nature of the conflict.

The Agila versus Ngbo communal conflict is over a disputed portion of about ten kilometres stretch of boundary between Ebonyi and Benue States. The conflict at its emergence during colonial era was an occasional minor skirmish that never resulted in any loss of life except for destruction of few huts and farms on the disputed land (Otokpa, 2014). But it remained perennial. Increasing population, migration and inexorable demand for land for economic activities have ensured that the frequency of the conflict is continuously on the rise. The formal demarcation of the boundary through Legal Notice 126 of 1954 by the colonial government brought some respite to the area until the Civil War of 1967 broke out. The entire Agila community was displaced by the Civil War. They returned to their ancestral land in 1970 to settle after the war ended. 
According to Otokpa $(2014$, p. 31), the settlement pattern of the border communities is determined by twin factors of "economy and security". The able-bodied young men inhabit the satellite villages to ward off any expansionist tendencies from their neighbours as well as engage in agricultural activities. There is also the traditional headquarter which is the centre where all clans live in clusters.

Agila population is distributed into two major settlement patterns. They are the main Agila town and satellite villages. The traditional headquarters otherwise called Agila is where the whole twelve clans of Agila made up of Ogbilolo, Osudu, Efoha, Osiroko, Efopfu, Anmeta, Otokilo Anidu, Akpoge, Okpatobom, Onogwu, Okpakor and Onwa setlle in clusters. Each has a public village square where they carryout social activities.

A large population made up of young men and their immediate families settle in the satellite villages to check any expansionist tendencies from neighbours, provide security in any case of external aggression and engage in agricultural and other economic activities. It was in these satellite villages numbering over fifty that the conflicts between Agila and her neighbour were restricted to before the Civil War. Otokpa (2014, p. 171) identified some of the villages as Okpere, Ole Ona, Uweye, Ole Idoko, Ole Obakpo, Ole Ogbueja, Edeke, Ogbolojo, Ole Aboyebe, Ole Onmeje Ocha, Ole Obagwu, Ole Ogbike, Ole Obakpoma, Ole Agu, Ole Adai, Eyatse, Ole Attah Enese, Odegema, Oloowo, Ole Ajayi, Ole Oja Ukporo, Ole Anmeta, Ole Ogenyi and Okpampa. Others are Okpaope, Olusamoga, Agazi, Ole Eho, Ole Otseno, Ole Idu, Ai Otokilo, Ole Egba, Okpeko, Araba, Okpadu, Iko and Agbada.

There was resumption of hostilities after the Nigeria Civil War as the provisions of the Notice 126 of 1954 was undermined. The Ngbo community, as alleged by Agila, encroached into Agila land in disregard of the 1954 demarcation by the colonial government (Agila Position Paper to Joint State Peace Meeting, 2004).

\section{Agila and Internal Population Displacement}

The complexion of the inter-communal dispute changed in what could be termed the second phase of the conflict after the Civil War as it acquires new character in terms of intensity and scope. Increasingly, the use of sophisticated arms and ammunition was introduced into the dispute thereby increasing its intensity. But it was in the 90s that population displacements resulting from both inter and intra-communal conflict started.

It was first the inter-communal conflict that made displaced residents of some satellite to migrate to the central Agila town that serves as the traditional headquarter. This was followed by the intra-communal conflict between royal and non-royal families in 1997. Displacement of residents in the latter conflict affected only those living in Agila town majority of who moved to Apa Ward. By 2003, all the satellite settlements mentioned earlier where most of the Agila agrarian population resides to engage in farming and hunting activities were sacked. They could not contain the incessant attacks and were forced to migrate. Not less than 10, 000 people, according to Jerome Omogo have been displaced from Agila (interview, Agila, July 27, 2016)

Since 1999, the scope of the conflict has expanded, as Agila town has become the main target as the satellite towns that acted as security outposts and check against external aggression have been sacked. Some of those displaced from the satellite villages are now forced to go on second migration. According to Otokpa (2014, p. 173):

Within Agila town, destruction of buildings and other infrastructure was total. Public properties destroyed by Ngbo were; Community Dispensary, Basic Health Centre, Maternity Centre, St Peter's Primary School II, LGEA Primary School I, LGEA Primary School, Ogbilolo, Universal Basic Education (UBE) Secondary School, Government Secondary School, Community Secondary School, Deeper Life Church, Methodist Church, Residence of Catholic priest, Apostolic Church, Public Power Supply Feeder Pilar (sic) and Area Development Office.

As the conflict persists, the capacity of Agila town as a fortress to those displaced from the satellite villages was weakened owing to incessant attacks. Not even the presence of some mobile policemen stationed in the community has helped to prevent attcks. More than half of the population of the 
community has been displaced (interview with Omogo, 27 June 2016). The new phase of the conflict, which has some elements of banditry, (Otokpa, 2014; Agila position paper, 2004) has made Agila unsafe. The frequency of attack has been on the increase. This was acknowledged by Newsdiaryonline newspaper in the following words:

Between December 2015 and January 2016, not less than 23 attacks were visited on Agila in Ado LGA of Benue State by armed militia from Ngbo in Ohaukwu LGA of Ebonyi State in a protracted border conflict the Federal government must quickly resolve to stop a degeneration to the magnitude in the North East (Newsdiaryonline, February 2016, para. 1).

This is largely due to the framing of the conflict in ethnic terms, in order to attract ethnic solidarity. The inter-communal conflict is fast assuming a new dimension following allegations of involvement of external interests. This was captured in a newspaper report thus. "In May this year, it was gathered that the Ngbo people invaded the Agila community and hoisted a flag of the defunct Biafra on the land as part of celebration of the burial of the Biafran warlord, late Odumegwu Ojukwu" (Babajide, Tribune, 8 July, 2012).

The current framing of the conflict in ethnic terms will likely mobilise more people within and outside the two communities to be involved in the fight for the control of the land. What should have been a land dispute between Agila and Ngbo communities is being elevated to the status of a conflict between North and East geo-political zones as depicted by a newspaper report (Tribune, 8 July, 2012). It complicates attempts at resolving it because the locals no longer have exclusive control over the dynamics of the conflict. The increasing frequencies of attacks since 1999, which are violations of series of peace talks between Benue and Ebonyi states are testimonies to this fact.

The effect of these violent clashes on Agila community has been catastrophic. The size of the community has been drastically reduced, so also is the population therein. The community population has been badly depleted as people are forced almost on daily basis to migrate. This migration, which includes workers on essential services like health and education, has badly affected livelihood in the community (interview with Jerome Omogo, Agila, 27/6/2006). The situation manifests sense of insecurity that retards every form of productive venture (Otokpa, 2013).

\section{IMPliCATIONS OF CONFLICTS ON LiveliHOOD SECURITY IN AgILA}

For a community that has been involved in a protracted conflict for nearly a century, it is expected that Agila must have gone through and still going through very difficult times. But the situation in Agila is not a function of the communal conflicts alone. It is also an expression of the fragile nature of the Nigerian State that is increasingly proving incapable of providing security and basic and fundamental necessities of life to the people (Egwu, 2006). This has had dire consequences on livelihood security in Agila.

For livelihood to be sustainable there are conditions that must be prevalent. Following the DFID Sustainable Livelihood Approach (SLA) five factors: physical, social, natural, economic or financial and human capitals are fundamental in the analysis of individual, village or group livelihood. According to Otse Otokpa, a former chairman of Ado Local government and an indigene of Agila, "There is no means of sustainable livelihood in Agila community" (Interview, Makurdi, 20/6/2016). Most fundamental for analysis of livelihood in Agila are four of these assets: physical, social, human and economic capital.

For instance, physical capital, which broadly refers to infrastructure, such as roads, buildings, and production are non-existent or in deplorable condition. Agila was linked with only one motorable road from Benue axis, which was constructed in the early 80s. Mr. Otse Otokpa, an Agila indigene and former Chairman of Ado Local Government said, "The people exist completely at the mercy of God because from every indication they have been abandoned by the government. Agila has no good access roads and has been cut off from the rest of the state because of the terrible condition of the Agila-Igumale road" (Interview, Makurdi, 20/6/2016). The situation is worsened by the fact that most commercial vehicle drivers would neither risk their vehicle on the long stretch of pot hole-strewn road nor their lives going to Agila referred to now as 'Afghanistan' because of the incessant violent attacks. 
Electricity supply, which would have enhanced production activities, is epileptic because of constant vandalisation of the supply line to Agila community from Otukpo as a result of the conflict. The destruction of public buildings like churches, schools and clinics has reduced the number of buildings for social services as most of them now operate from makeshift locations in relatively safe places with the centre of the town. Some of the facilities affected are the Community Dispensary, Basic Health Centre, Maternity Centre, Development Area Office, Community Secondary School and Government Secondar School.

Displacements owing to inter and intra-communal conflicts have both affected social relations and group formation in the community. The intra-communal conflict between royal and non-royal groups brought disunity and mutual hatred that tore the community into two. In extreme cases, marriages were dissolved and friendship ties broken. The conflict uprooted a large number of members of the community from their ancestral homes leaving them with deep feelings of hate toward their opponents. The situation has been exacerbated by the massive displacement caused by increasing frequency of violent conflict between Agila and Ngbo, which has put Agila town under pressure since 1999. Most families have been separated as vulnerable members migrate to safety in other towns and villages.

Probably the most affected asset in the conflict is the economic capital. Before the conflict took this new dimension Agila was a prosperous rural community growing the dominant food crops like yam, cassava, rice, cocoa-yam, etc. They fed surrounding local markets with these produce. The conflict displaced most of the producers from the satellite villages where they lived to engage in agricultural activities thereby dislocating economic activities. Consequently, food production has dropped drastically beyond subsistence level so also is the income of the residents, majority of whom are dependent on farming.

Human capital is another asset that has been negatively affected by the long years of conflicts and consequent displacement. The drastic reduction of population means few hands are available for labour. Even the young people available spend more time providing security in vigilant operations. The picture is painted clearly by Otokpa (2013, p. 174) thus:

Not just that farms are being destroyed, farm work generally is threatened due to high sense of insecurity. Young adults who ought to be in the farm or engaged in other productive chores are forced to take up emergency vigilante work in order to help the police protect the community against imminent Ngbo invasion. The future of children in Agila is in jeopardy because their education has come to a standstill following the destruction of their schools.

The implication is that productive hours are wasted and opportunity of any form of skill acquisition or formal education is difficult to come by. Government workers posted to Agila often reject it on plausible grounds of insecurity (interview with Jerome Omogo, Development Area Officer, 27/6/2016). This has created dire livelihood insecurity in Agila.

\section{ConClusion}

Communal conflicts (inter and intra) in the categories of resource or identity based have the capacity to generate humanitarian problem such as population displacement and its attendant challenges. Population displacement on its own poses serious threat to sustainable livelihood. The destruction of assets such as physical, social, economic, human and natural capitals considered as inevitable sources of sustainable livelihood inexorably lead to livelihood insecurity.

Derived from the condition prevalent in Agila community occasioned by nearly a century-old conflict as examined earlier, this paper concludes that Agila is facing a dire situation of livelihood insecurity. This position is underscored by the manifest challenges posed by lack of access to physical, economic, social, and human capital.

While the conflict is perceived as local it has the capacity of escalating to a higher level with serious consequences for national security because of its location. Protracted communal conflict yield to a tendency of framing with the objective of mobilising ethnic solidarity. The Agila/Ngbo communal conflict exhibits this character because the parties do not only belong to different ethnic groups (Idoma and Igbo) but to different local governments (Ado and Ohaukwu), different states (Benue and Ebonyi) and different geo-political zones (North and East) that have a history of mutual suspicion and antagonism. 


\section{RECOMMENDATIONS}

From the above conclusion we make the following recommendations to mitigate the situation:

1. Urgent Intervention: Urgent Federal and state government intervention is recommended to manage the conflict to prevent possible escalation through a deliberate action that will include deployment of more security personnel to the area. There is the urgent need to address the challenges being faced by the people in a way of humanitarian assistance to alleviate their deprivations.

2. Provision of infrastructural facilities: The federal government should as a matter of priority construct the road linking Benue with Ebonyi State to open the two communities locked up by lack of accessible roads. This will check the nefarious activities of gunrunners that tend to have increased the proliferation of arms in the conflict zone. The need for security outpost at the boundary like a military barrack will serve as a buffer zone and boost the confidence of people to move freely in the area.

3. Conflict Analysis: There is the urgent need to undertake a thorough analysis of the conflict to understand its background, causes, dynamics, parties (direct and indirect) and their positions. This will help in redesigning a new approach that will provide grounds for the resolution of the conflict.

Most importantly, it is recommended that the federal government should play a critical role in the conflict resolution process as a third party. This should be done with objectivity in the spirit of equity and fair play in order to win the confidence of the parties.

\section{REFERENCES}

Babajide, J. (2012) Benue-Ebonyi communities border dispute: 'our children cannot go to school, neither could our women go to the market nor farmers engage in their farming activities, Tribune newspaper report. http://www.tribune.com.ng (accessed June, 15 2016)

Best, S. \& Idyorough, A. (2003), Population displacement in the Tiv-Jukun conflict, in O. Nnoli (ed) Communal Conflict and Population Displacement in Nigeria, Enugu, PACREP Book Series, 1.

Blench, R. (2004), Natural Resource conflicts in north central Nigeria. Cambridge, Mallam dendo Ltd.

Brosche, J. \& Elfversson, E. (2012) Communal conflict, civil war and the state: Complexities, connections and the case of Sudan. African Journal of Conflict Reoslution. 12, 1

Chambers, R. \& Conway, G.R. (1992), Sustainable rural livelihoods, practical concepts for the $21^{\text {st }}$ century. Brighton IDS Discussion paper No. 296.

Elfversson, E. (2013), Third parties, the state and communal conflict resolution: A comparative study of evidence from Kenya. Paper presented at the Thomas Olson Memorial Conference, Uppsala. April $18-20$.

Egwu, S. Salihu, A. \& Kure, E. (2003), Communal conflict and population displacement in Zango-Kataf in O. Nnoli (ed) Communal Conflict and Population Displacement in Nigeria, Enugu, PACREP Book Series, 1.

Egwu, S. (2006), beyond revival of old hatreds: the state and conflict in Africa, in Best S.G. (ed) Introduction to Peace and Conflict in West Africa. Ibadan, Spectrum Books Ltd. Pp. 406-443

Gaillard, J.; Maced, E; Stasiak, E.; Le Berre I. and Espaldon, M. (2009), Sustainable livelihoods and people's vulnerability in the face of coastal hazard: In: Journal of Coastal Conservation 13 (2) 119129 DO1:10:1007/s11852-009-0054-7

Ibeanu, O. (2003), Communal conflict and population displacement in Nigeria: An exporatory analysis, in O. Nnoli (ed) Communal Conflict and Population Displacement in Nigeria, Enugu, PACREP Book Series, 1.

Morse, M; McNamara, N; \& Acholo, M. (2009), Sustainable livelihood approach: A critical analysis of theory and practice. The University of Reading, Geographical Paper 189, November.

Morse, M. \& McNamara, N. (2013), Sustainable livelihood approach: A critique of theory and practice. http://www.springer.com/978-007-6267-1. (Accessed June 20, 2016) pp. 15-60. 
Nnoli, O. (2003) Communal conflict and population displacement: An introduction, in O. Nnoli (ed) Communal Conflict and Population Displacement in Nigeria, Enugu, PACREP Book Series, 1.

Oinokwu, M. (2016), Agila: The deaths, blood and pillage of insurgency, posted by http://www. newsdiaryonline.com News, Security article meta. February 23, 2016 (accessed June 23, 2016)

Otokpa, O. (2013), Agila/Ngbo: Critical evaluation of a border conflict in Nigeria. Makurdi, Oracle Publications Limited

Sakdapolrak, P. (2014), Livelihoods as social practices - re-energising livelihoods research with Bourdieu's theory of practice. Geograhica Helvetica, April 2014, pp. 18-26. Retrieved $29^{\text {th }}$ June 2016 from http/www.geogr-helv.net/69/19/2014/doi:10.5194/gh-6919-2014

Scoones, I. (2009), Livelihoods perspectives and rural development, J. Peasnt Stud., 36, pp. 171- 196.

United Nations (1998), Guiding Principles on internally Displace Persons

Women Enviromental Programme (2009), Conflict in the middlebelt region of Nigeria: Engendering peace in Agila community. A UNDP intervention programme with WEP, Abuja, published by Women Environmental Programme. 